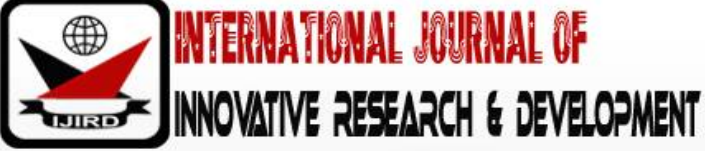

ISSN 2278 - 0211 (Online)

\section{Comprehensive Citizens Data and Effective Elections in Nigeria: The Role of Information Communication Technology (ICT)}

\author{
Igboechesi Paul Gilbert
}

Assistant Librarian, Department of Library, University of Jos, Nigeria

\begin{abstract}
:
Regular elections form one feature of democracy, participating in it as a citizen is one of the main elements of democratic performance and dividend; this is because citizens' participation in electoral and political process is central to the society's development or underdevelopment. This makes Elections and the ability of citizens to vote (and choose their leaders), not just important but integral to the viability of any society. It goes to show that the processes needed to achieving a proper voting system must not just be okay, but tenaciously and meticulously okay. Therefore, the citizens' data bank of Nigeria is expected to be not just a segmented or periodical one but a whole and on-going one to enhance the quest for the attainment of a viable electoral process and meaningful development. This article will be looking at the many aspects the Nigerian elections is in dare need of upgrade to meet the very needed pace of ensuring a credible process in choosing our leaders, hence the role and place of Information Communication Technology (ICT) in the entire process as a panacea to the long overdue upgrade.
\end{abstract}

Keywords: Elections, Permanent Voters Card (PVCs), Information Communication Technology (ICT), Independent National Electoral Commission (INEC), Voting, Democracy, GPS (Global Positioning System), Electronic Voting Machine (EVM), Electronic Voting (EV)

\section{Introduction}

Since the end of the cold war, democracy has been a leading system of governance for many nations seeking to attain liberal governance in its highest level feasible. This is why democracy is often attributed to development. Prior to democracy, monarchy used to be the form of governance in place, with its acceptance by some successful nations, it now spread like "a burning bush in the harmattan season". It caught up with Africa in the 90s, because the clamor and general discontent with impunity, corrupt, inefficient, repressive and dictatorial systems of governance had gone to a level of worry for not just Africans but the world at large. In all of these, Nigeria was not left out, because one key area of democratic process, elections and voting, started even in the pre-colonial Nigeria.

In the case Nigeria however, it has had questionable elections dating back to 1922 (pre-colonial period) to 2015 (post-colonial period), battling with incessant problems associated with the ability to conduct free, fair and credible elections. All past elections in the post-colonial (especially in the fourth republic) Nigeria were characterized by gross irregularities, ranging from multiple registration of voters, multiple voting, falsified and incomprehensive voter register, disenfranchisement of eligible voters, thuggery and rigging, snatching of ballot boxes, manipulations and mutilation of election results amongst the political class, under-aged voting, buying of voters' cards for unregulated and unsupervised voting, hiring of machinery voters from neighboring countries etc. this, directly or indirectly, caused post-election violence in South-West in 1965, 1983 and 2003; North-East, North-West and North-Central in 1965, 2011, which claimed over 5000 lives and destruction of properties. Party supporters clashed severally with opponent groups at various locations in one election or the other, and over 3000 people were reported to have been killed. For close to 20 years since the return of democracy in 1999, elections have been won by hook or crook or better still, the best rigger.

Democratic societies are founded on the principles of elections because citizens express their right through the conduct of election in choosing a leader whom they believe their nation's destiny can be entrusted with. This prompted election management bodies around the world to introduce innovative processes, most of which are now considered best practice to improve the management and conduct of elections. Central among them is the use of information and communication technology, to aid the attainment of a more effective and transparent processes.

For Nigeria, a new political step, to information and communication technology (ICT) was first introduced by Independent National Electoral Commission (INEC) in 2003 to register eligible voters and compile credible voters register with a view to consolidating her democracy. The usage of ICT in was seen as a very pertinent one, as it was expected to eliminate, primarily the case of multiple registration, which had been one of the main political tools for rigging elections. This unique technique was employed to capture mass involvement in governance and empowerment of the teeming electorates to participate in electoral processes. The innovation was largely welcomed by Nigerians because it was meant to showcase governance in Nigeria with the fundamental challenge to excel. INEC sustained the tempo of the achievements 
recorded in previous exercise by reintroducing ICT mechanism in 2007 elections in updating the voters register, and in other subsequent elections.

\section{Clarification of Concepts}

Concepts that are close with this presentation will be clarified in this section of the study. They include: Elections and Information Communication Technology (ICT).

\subsection{Elections}

This has to do with the process by which the people of a place choose those who will represent them in government. The process takes place in order to fill public offices at various level of government be it federal, state or local. As stated earlier, it is a major feature in a democratic system and this is because the people must have their voices heard and opinions valued in their leadership and in key decision making if such form of government is to be considered a democracy.

\subsection{Information and Communication Technology (ICT)}

The United Nations Economic Commission for Africa (ECA) (1999) sees ICTs as covering internet service provision, telecommunications equipment and services, information technology equipment and services, media and broadcasting, libraries and documentation centres, commercial information providers, network-based information services, and related information and communication activities.

According to Afriyie (2012), ICTs cover any product that receives, stores, retrieves, manipulates or transmits information electronically in a digital form such as personal computers, digital television, email, robots, etc. It embraces all the uses of digital technology that already exist to help individuals, businesses and organizations use and manipulate information. It also concerns the way these different uses can work with each other. In relation to business.

\subsection{Elections in Nigeria}

When it comes to elections in Nigeria, one of the basic problems embedded in the whole process is the issue of over blotted analogue processes. Apart from the DDCM (direct Data capturing Machines) introduced in 2007 which produced the Electronic Voters' Register and smart card readers which has since been used for registration of voters and authentication of finger prints and PVC, used for all elections. The rest are largely left for paper-analogue parts. You find that lots of materials are moved around every election, large number of ad-hoc personnel running into billions of Naira are employed, people travel around the country during elections to vote where they actually registered, and other cases such as:

- Alteration of results after collation; pointing to another problem, compromise of the ad-hoc staff.

- Using unqualified personnel for collation of results, this leads to inaccurate results and cancelation of collated results.

- Ballot box snatching and destruction by hoodlums sponsored by Politicians.

- Unnecessary tension the prolonged time of collation causes in the land.

- Diverse forms of false results cooked up by politicians and political parties in the process of waiting for election outcome for days.

- Not forgetting the problem of terrain: environmental challenges in carrying these materials to difficult parts of the country, some are not even motorable.

- Multiple registrations still not totally eliminated, even with the current Automatic Fingerprint Identification System INEC is using to check it. There are still cases of people with double voters' card, who registered in different states or polling units.

- Under age voting; this is a direct product of poor National Data Grid for Nigerian citizens.

- Rigorous stress people go through before registering as an eligible voter and also the case of

- The huge amount of money used for the printing of the Permanent Voters Cards (PVCs) outside the country.

- Frustrating process of collection of the PVC which theoretically appears to be a simple process in terms of words but not practically so for a good number of citizens when you finally go for collection. This can be substantiated with the Presidential voting turnout in Nigeria from 1999 to 2015:

$1999=52 \%$

$2003=69 \%$

$2007=57 \%$

$2011=54 \%$

$2015=44 \%$

Source: Independent National Electoral Commission (INEC).

From the above, it is clear that the advent of the PVC has greatly affected the voter turnout in Nigeria, notice the sharp decline from 2003 when it was the highest (with 69\%) up to 2015. It is clear that the process is also not very dulceting to Nigerians for reasons bordering majorly on the time wastage and gross incompetence experienced in the course of registration, collection of PVCs and even voting.

In all of the above sated, these challenges can actually be greatly reduced with the integral usage of ICT in the Nigerian elections. Granted that a lot of postulations about Nigeria not being ripe for ICT-inclined elections have been made by some (e.g.): 
The Executive Director, Foundation for Good Governance and Democratic Change, Austin Osakue (2019), opines that "adopting electronic voting at the current stage of Nigeria's development, rather than a gradual approach, will be a disaster".

Osakue added that:

"For you to successfully implement an agenda of electronic voting, your power infrastructure must be intact... Power is almost non-existent in this country. The use to which we have put the Internet or ICT in this country does not encourage anyone to advocate full-blown electronic voting." ... "What I will canvass is a gradual ascendancy. First, let us get the card reader working and make it reliable so that registration will be totally electronic and people can walk into any centre and register at any point in time".

For Prof. Eddie Erhagbe (A lecturer in the Department of History and International Studies at the University of Benin: 2019), he said that "the country lacked stable power needed to ensure the seamless use of technologies in elections, in addition to fraudulent manipulation that they could be subjected to"

He added that:

"In terms of infrastructure, we are still lagging behind; a lot of things still need to be done in

a country where power supply is epileptic or not available at all. For you to get the

electronic system to work it would depend a lot on the availability of power".

While all these are placed, let me quickly remind us that Nigeria is yet to meet up with international standard for the provision of viable, successful and generally accepted electoral system of democracy due to lack of full implementation of the required electronic voting system in the county that entails combining electronic voters register and smart card readers with election result devices that would be self-auditing and fully equipped with real time facilities. Because It is believed that the full implementation of the required electronic voting system in Nigeria would improve election management in the country thereby meeting up with international standard. What this article posits is the reality on ground: Nigeria is too Big to have a credible election in the analogue form right now. Doing this and getting it right might not be very easy but taking the bold step of Moving forward is pertinently required right now. Imagine the reason the INEC chairman, Prof. Mahmood Yakubu, gave in his nationwide address on the postponement of the general elections slated for 16th of February 2019 by one week:

"Following a careful review of the implementation of its logistics and operational plan and the determination to conduct free, fair and credible elections, the commission came to the conclusion that preceding with the elections as scheduled is no longer feasible"...(Mahmood, 2019)

From the above, the primary reason was the inability of the body to distribute the required electoral materials on time, in the name of logistics!

\section{Addressing the Nigerian Elections Challenge}

Primary to the drastic measure of getting it right includes the prompt need for what I call "Unified National Identification Number" (UNIN). As the name implies, Nigeria needs a robust citizens' data base that is unified (as seen in other countries). Different agencies that are involved with citizens' data should be able to work with one database. Today in Nigeria, you find that in getting your driver's license, you need a separate database for that, because going to the bank means another one altogether, getting your car papers is also not the same. Every citizen should be made to have a UNIN immediately they are born, and for those already existing, they should be made to register. This should become the life line of the society in all spheres: registration for schools at all levels, shopping, banking, vehicle licensing, national and international transactions, Subscriber Identity Module Card (SIM-Card) criteria for registration etc. By so doing, the near possibility of getting a reliable data for the citizenry is achieved not only for elections but for all other purposes. This will go a long way in helping the country make good projections with trusted data and figures e.g. Number of unemployed citizens and their age gaps, number of underemployed citizens and their age gaps, near accuracy of child birth and death data etc. When time for elections comes, the craze for PVC registration will no longer be there, any citizen up to voting age will be automatically activated. Voting should now depend on your UNIN (which will encompass your prints, photo, and facial recognition gadget) not PVC, just a NUMBER! The feeling of being a segregated member of the society will spur citizens to be part of it.

\section{The Independent National Electoral Commission (INEC) Issue}

It is widely believed that the key aspects of an election are accreditation, voting, counting of votes, collation of poll results and the declaration of the final results. The Independent National Electoral Commission's guidelines stipulates that the electorate are to exercise their right to vote through an accreditation process done with the use of INEC's Voters Identification System (IVAS) popularly known as Smart Card Reader (SCR) or incident form, under the Electoral Act, 2015. This means that voters will be at their designated polling units between 8am and 2pm as stated by the guidelines, joining a queue and presenting their Permanent Voter's Cards to polling officers when prompted. The polling officers are expected to confirm that the photographs on the PVCs match the faces of the voters, if their names are on the voter's registers for their respective polling units. There is also the checking of fingers prints of the voters and the ink mark on the cuticle of the tomb (the dead skin at the base of a fingernail) of the voter to avoid double-voting, before ticking the register and giving back the PVC to the voter.

According to INEC, the staff of the commission is expected to stamp the back of the ballot paper, write the date of the election, append their signatures, fold it vertically to cover the printed side and hand it over to the voters, who also 
would have their thumbs inked in order to thumb-print (vote) on the section provided for their preferred candidates or political parties on the ballot papers. After which the voter is expected to fold the printed side of the papers vertically and drop them into the ballot boxes provided by INEC. The commission further states that at the end of the voting exercise, the ballot papers are counted and collated to determine the number of votes cast, valid votes and total number of votes scored by each of the candidates or political parties at the various polling units from the local government areas to the national level.

While INEC and largely the government believes that the electoral procedure currently in use fosters public confidence and the credibility of elections in Nigeria, recent elections in the country have shown that the process is susceptible to irregularities ranging from faulty card readers, falsification of results, multiple voting, invalid votes, vote buying, underage voting and ballot box snatching to destruction of ballot papers. Such cases were widely reported in the 2011, 2015 and even the 2019 elections. How about the reports of faulty card readers, among other forms of irregularities, during the 2016 governorship elections in Edo and Ondo states, the 2017 governorship poll in Anambra State and the 2018 gubernatorial elections in Ekiti and Osun states. After the 2019 Presidential elections, the European Union Election Observation Mission Nigeria (EU EOMN) in their preliminary report had a press release with the following header: "Serious Operational Shortcomings put undue burden on voters, civil society; civil society enhanced electoral accountability". In the body of the press release, the Chief Observer, Maria Arena noted the following:

- INEC operated in a difficult environment...

- There was the need for regular communication...

- Postponement of the election and the delayed start to voting, placed undue burden on voters...

- Polling Procedures were not always followed, and in 14 per cent some materials were missing...

Going by all these observations, there is a clarion call for Nigeria to adopt a more holistic but sophisticated approach in the use of ICT during general elections that goes beyond the card reader. This call cites that many countries practicing modern democracy have embraced electronic voting and transmission of results due to its ability to ensure that votes count with ease and with minimal errors. Prominent among these calls is the international community.

Haven placed all the above, I make bold to say that INEC as a body, is over bloated! Hence the need for it to be dismantled. For example, the registration of citizens (data collection) for election should be a thing for a separate body e.g. National Identity Management Commission (NIMC) and or National Population Commission (NPC)etc., carrying this out as a regular day to day priority or objective, based on the posited above. INEC should only make use of the collated data from these bodies or body (in the case of using just one of them). In the area of orientation, the National Orientation Agency (NOA) should be central in it. INEC should only concentrate on the elections proper, bringing up ways to make it work.

On the part of the "over paperized" current system of INEC, customized computer systems with double or triple battery capacity should be carefully designed with wide screens and special live feed web cameras that will be the eye of the national body in all polling stations with special codes and uniqueness for each state (a situation where the system for Gombe State cannot be used in Plateau State) in the process. This should include highly designed long lasting external batteries as well because of the power issues in Nigeria. All of these can be built into a briefcase with different compartments with GPS (Global Positioning System) and tracking functions. Sat phones should or may also be included as a backup GPS or send SOS (Save Our Soul) messages. This is because data connections come standard with most satellite phones and gadgets. All should have a direct satellite connection remotely controlled from the INEC Headquarters. The possibility of achieving this is not farfetched as we already have phones that operate even where there is no network, e.g. Iridium Extreme 9575, Iridium 9555, Iridium 9575 PTT, Is at Phone 2, Global star GSP-1700 and even the popular Thuraya (world's most advanced satellite phones). Such systems can be built with technologies that will not only rely on satellites but even on the local networks, as extreme backup (with strong boosting capacities). This will go a long way in eliminating all the so called sensitive and in sensitive materials because INEC will be the one to give live feed to all with the necessary soft materials when needed.

\section{Implications of an ICT Driven Elections}

The above will give meaning and prestige to the Nigerian election because citizens will be able to vote from anywhere in Nigeria, thereby ending the case of unnecessary Public Holidays for people to travel and endangering their lives and properties in an already existing bad road networks all over the country. The aspect of under aged voting is drastically eliminated because the system is only using a UNIN that can only activate a voter, the case of having a voter's card with an adult age for an underage is wiped and the problem of double registration is eliminated by virtue of the central system every registration goes into directly and immediately. The case of ballot box snatching is also packed up forever, as voting will now be electronic, validated by your thumb print, index or order wise. There is also the case of elimination of invalid votes, the computer will only accept one vote (for each segment) and nothing more. The number and logo of all political parties involved in the election is visible on the primary screen (easy user-friendly environment) for citizens to touch and vote after going through a tech-security-based checks. The case of unnecessary time wastage is also reduced as people will experience great sense of relief in the process, rigging of elections by desperate politicians by reasonable standards become a wishful exercise, as the system is designed to know the number of votes expected from each polling unit, local government, state and nation at large. Any attempt to go beyond it is rejected by the system. Thereby keeping the elected into office in their best form to perform or risk rejection. And most of all, results will not have to be transported to Abuja but it will be an on the spot assessment issue, reading life for the world to see. The outcome is followed on the official electronic table and or website of the electoral body as people vote. By the end of the voting, citizens already know the outcome; the electoral body only does the official declaration as demanded of them by the constitution. Nigerians must not wait for days to know who their leaders will be, it can be decided in a day! Interestingly, 
this platform will also make it easy to finally inculcate Nigerians outside the country in the voting process, as it is currently placed in South Africa now (citizens abroad now vote).

Accepted that there will be challenges of Finance, as this is going to be capital intensive (in training and gadget purchase), it is also apt to quickly note that there is no price too much for a viable democracy because this plays a pivotal role in attaining such. The problem of hacking is also not misplaced as it is Information Technology (IT) great measures like having multiple dedicated servers in all fronts and spheres, layers of security software and specialist in ICT championing the entire process with in-depth security phases that can only be activated by key INEC staff, capped by the chairman, will go a long way to avert such. The problem of computer literacy is also another concern, on this, it is expected that the platform for the electronic voting is made as a replica of what they are used to in paper, only this time, it is electronic, they only need to touch. Better still, vigorous voter education will be put in place with dummy platforms for citizens to comprehend the trend, as seen in Namibia's 5th elections since independence in 2014. Its however possible that the height of the processes might not be achieved at once, but as it progresses, more feat will definitely be achieved.

Beyond all that has been said, the country will go a long way in ending pre and post-Election violence, increase in citizens participation as a result of trust on the system, high level accountability on the part of the elected officials which translates to developmental democracy and not what we currently run; retrogressive democracy.

\section{Conclusion}

In stressing the importance of ICT in the management and conduct of elections, Jega (2012) notes that: "Election management bodies around the world have employed a number of innovative approaches, some of which are now considered best practice, to improve the management and conduct of elections. Electoral reforms that have been instituted include the use of information and communication technology, adoption of more transparent and inclusive processes, professionalization of the organization, amendments to legal framework and improvement of relationships with external stakeholders. As a result of these efforts, the past several years has seen the varying successes of a number of election management bodies in the manner by which they prepare, organize, administer and conduct elections" (Jega, 2012).

During the 2008 United States Presidential elections, Barak Obama broke the world record in the history of ICTs use for political purpose. Since then, many nations and politicians across the globe have continued to embrace the platform to mobilize their citizens and candidates towards active participation in the political process. Namibia became the first African country to use Electronic Voting Machines (EVM) in 2014, according to the Namibian electoral commission's Theo Mujoro;"The decision to consider acquiring electronic voting machines was primarily based on some challenges and experiences that we have had in the manner and way we manage our elections". The Officials said" electronic voting (EV) will speed up counting and reduce queues for Namibia's 1.2 million voters". Just 1.2 million voters, how about a country with over 80 million registered voters? VNigeria's case should not be seen to be divergent on this as this is now the path to effective and sure electoral process and results.

ICTs have become a platform for interaction and all-encompassing participatory medium for all; lives are to build around it. For Nigeria, the year 1999 gave birth to a shift in paradigm from the military era to a new dawn of democratic journey. Prior to this period, modern electoral processes have not been imbibed, but 2011 political dispensation (and 2015 by extension), heralded the use of ICT's in electioneering processes. Political parties, candidates, civil society organizations, INEC, security agencies and the electorates used it for enlightenment and to canvass for votes and support where necessary, it is now the turn of the electoral process, just like in Canada, United States of America, India, South Korea, Venezuela etc. The government and all stakeholder mentioned hitherto should ensure that the full digitization of the electoral process is achieved by bringing up a befitting template and imbibing them into our electoral act to make them legal. The Namibian process may or may not have gotten the desired end, but the fact is that they have taken the bull by the horn, and they must surely be in the process of making it better. We Never Know How High We Can Fly Untill We Try!

\section{References}

i. Arena, M. (2019. Chief Observer, Presidential Elections, the European Union Election Observation Mission Nigeria (EU EOMN) preliminary report: "Serious Operational Shortcomings put undue burden on voters; civil society enhanced electoral accountability". 25th February, 2019

ii. Ayeni, P.T. \& Esan A. O. (2018) The Impact of ICT in the Conduct of Elections in Nigeria. Article Jan (2018). http:/ / www.imedpub.com/ articles/ the-impact-of-ict-in-the-conduct-of-elections-in-nigeria.php?aid=22211

iii. Brown, B. The Best Satellite Phones. https:/ / www.digitaltrends.com/ outdoors/ best-satellite-phones/

iv. Esan, A.O., Ayeni P.T. (2018) E-Voting in Nigeria: Barriers to Full Implementation. J Comput Eng Inf Technol 7:3. doi: 10.4172/ 2324-9307.1000203

v. Umana, $\underline{K}(2008)$.Causes of Voter/Political Apathy in Nigeria. https:// researchcyber.com/ causes-voter-politicalapathy-nigeria/

vi. Mahmood Y. (INEC Chairman) Press Release "INEC Reschedules 2019 General Elections". 16th February, 2019.

vii. Namibian election first in Africa to use electronic voting machines. (n.d). Retrieved February 9, 2019, from https:/ / www.abc.net.au/ news/ 2014-11-28/ namibian-election-first-in-africa-to-use-electronicvoting/ 5927206. Posted 28 Nov 2014, 12:38pm

viii. Nwagwu, E. (2016). Information and Communication Technology and Administration of 2015 General Election in Nigeria. Mediterranean Journal of Social Sciences. 10.5901/mjss. 2016.v7n4p303. 
ix. Okere A. (2019). Elections and Enemies of ICT in Nigeria's Search for Credible Polls PublishedJanuary 5, 2019. https:/ / punchng.com/ 2019-elections-and-enemies-of-ict-in-nigerias-search-for-credible-polls/

x. Osabiya, B.J (2014). Nigeria and Democratic Elections. Journal of Good Governance and Sustainable Development in Africa (JGGSDA), Vol. 2, No 3, December, .2014. Website: http:// www.rcmss.com. ISSN: 2354-158X (Online) ISSN: 2346-724X (Print) Osabiya, Babatunde Joseph, 2014, 2(3):53-64

xi. Unwuchola, A.A., Adinlewa T.\& Udeh K. (2017). An Appraisal of the Role of ICT as a Tool for Participatory Democracy in Nigeria. http:/ / www.unimaid.edu.ng/ oer/ Journals-

oer/ Social/ masscomm/ MCC\%20Vol\%201\%20No\%201\%20June\%202017/ MCC\%20Vol\%201\%20No\%201\%201 Prelim\%20Pages.pdf 